The Market’s Perception of the Information Conveyed by Dividend Announcements

Linda Canina

Cornell University

* L.Canina, Cornell University, 448 Statler Hall, Ithaca, NY 14853. Tel.: (607) 2558051;

e-mail: lc29@cornell.edu

Helpful comments from Yaakov Amihud, Stephen Brown, Stephen Figlewski, William

Greene, Roni Michaely, William Silber, Bruce Tuckman and seminar participants at Boston College, Brown University and the University of Iowa are gratefully acknowledged. 


\begin{abstract}
This paper tests whether the market perceives announced dividend changes to reflect information about current and/or future cash flows. The empirical relationship between dividend changes and earnings changes is inconclusive. Furthermore, there is no empirical evidence regarding the market's perception of managers' intentions in changing the level of dividends. By analyzing the price reaction of scores to an announced dividend change, we are able to isolate the effects of a short-term change and a long-term change. Our findings indicate that the market perceives dividend changes to reflect a long-term change in earnings.
\end{abstract}

JEL classification: G14; G35

Keywords: Dividend announcements; Earnings changes 


\section{The Market's Perception of the Information Conveyed by Dividend Announcements}

Considerable research shows that there is a positive relationship between stock prices and dividend changes (Asquith and Mullins, 1983). The cash flow signaling hypothesis is a frequently suggested explanation of this result. This hypothesis asserts that managers use dividend announcements to convey their expectations about current and future cash flows to the market. ${ }^{1}$ Consistent with this hypothesis, Lintner (1956) documented that managers change dividends in response to an unexpected long-term change in earnings. Managers intend to use dividends to convey their information about future earnings to investors.

The cash flow signaling models assume a positive association between dividend changes and future earnings changes. Even though there is a positive correlation between stock prices and dividends, the empirical evidence about the relationship between dividend changes and subsequent earnings changes is mixed. ${ }^{2}$ For example, Watts (1973) tests whether earnings in year $t+1$ can be explained by current (year $t$ ) and past (year $t-1$ ) levels of dividend and earnings. Although the dividend coefficient was positive, it was not statistically significant. Gonedes (1978) found similar evidence. The results of Healy and Palepu (1988) show that the information conveyed by extreme dividend changes, initiations and omissions, is related to earnings changes following the announcement of these dividend policy changes. More

\footnotetext{
${ }^{1}$ A competing explanation for the reaction of stock prices to dividend announcements is the 'wealth redistribution' hypothesis. For a discussion of the wealth redistribution hypothesis see Black and Scholes (1974), Black (1976), Galai and Masulis (1976), Jensen and Meckling (1976), Kalay (1982), Myers (1977), Smith and Warner (1979), Handjinicolaou and Kalay (1984), Dhillon and Johnson (1994). Handjinicolaou and Kalay (1984) analyzed the relative importance of the information content of dividend hypothesis and the wealth redistribution hypothesis by examining bond price behavior around dividend announcements. Their evidence suggests that dividend announcements contain information about firm value. However, the results of Dhillon and Johnson (1994) differ from those of Handjinicolaou and Kalay (1984). Their results support the wealth redistribution hypothesis but do not rule out the information content hypothesis.

${ }^{2}$ See Watts (1973), Gonedes (1978), Healy and Palepu (1988), Yoon and Starks (1995) for empirical evidence on the relationship between dividend changes and future changes in earnings.
} 
specifically, they state that 'firms have earnings increases for the year of, and two years following, a dividend initiation; these increases appear to be permanent'. In contrast, for the sample of dividend omissions, they conclude that 'the earnings decline experienced by these firms before and after the omission announcement appears to be temporary'. That is, the decline in earnings before dividend omissions is reversed in subsequent years. More recent evidence, such as Yoon and Starks (1995), indicates that announcements of dividend increases and decreases cause analysts to revise their current earnings forecasts in a manner generally consistent with the cash flow signaling hypothesis. When they examined revisions of analysts' forecasts for future earnings, they documented significant changes only for dividend decreasing firms. Analysts do not significantly revise their expectations of future earnings for dividend increasing firms. This finding is important because previous researchers have not examined changes in long-run earnings expectations around dividend change announcements, although it has been frequently stated that dividend changes release mangers' information about both current and future cash flows.

The question that this paper addresses is whether the market's perception of dividend changes is consistent with management's intentions to convey information about an unexpected change in long-term or permanent earnings. The answer to this question is not obvious because the empirical evidence of the association between dividend changes and subsequent changes in both short-term and long-term earnings is inconsistent. Thus, this study derives and implements a test that examines investors perception of dividend announcements. Investors may perceive an announced dividend change to reflect an unexpected long-term (permanent) or short-term (temporary) change in earnings. From observing the reaction of stock prices alone to announced dividend changes, we are unable to discern the market's perception of the announcement. The 
stock price will increase if an announced dividend increase represents management's response to an unexpected change in earnings over both the long term and short term. As a result, it is impossible to distinguish between the two by analyzing stock price behavior alone. However, it is possible to distinguish between the two hypotheses by analyzing the impact of dividend changes on three different assets, namely the stock, prime and the score. These assets differ with respect to the timing in which the investor is entitled to the cash flows of the company.

Scores are European call options with 5 years to expiration, when issued. They only have claims on the firm as of the expiration date. ${ }^{3}$ Therefore, score holders are concerned about the long-run earnings of the firm. The prime holders receive the dividends until the expiration date. They have short-term claims on the cash flows. At expiration, they receive the minimum of the exercise price and the stock price. The stock holder has both short-term and long-term claims on the firm. The price reaction of each asset will differ because each has a claim on the firm as of a different point in time and for a different length of time. As a result, the analysis of these three assets allows us to distinguish between these two possible market interpretations of managements intention in announcing a change in dividends.

It is shown that when the market expects a dividend increase to reflect information about long-run earnings, the price of the score, the prime and the stock will increase. However, if the stock and the prime prices increase while the score price remains unchanged, this implies that the market perceives the information in the announcement to reflect a short-run change in earnings. The results indicate that the market perceives the dividend change to reflect a change in the longterm earnings of the firm, consistent with Lintner (1956).

\footnotetext{
${ }^{3}$ The average time to expiration is about 2.5 years.
} 
The rest of the article is organized as follows. In Section 1 the valuation equations for the score and the prime are derived. The relationship between the market's perception of the information content of the announcement and the price reaction of the score, prime and the stock is described in Section 2. This is followed by a description of the data and methodology in Section 3. Lastly, the results and the conclusions are presented in Section 4 and 5 respectively.

\section{The valuation of scores and primes}

Primes and scores are not issued by the firm but are created through the establishment of the Americus Trust. The Trust acts as a repository for common shares which are exchanged into units of the Trust. The units are divisible into two parts, the score and the prime. Primes and scores split the cash flows of a share of stock into a dividend and a capital gain component respectively. ${ }^{4}$ From 1983 to 1992 investors could purchase primes and scores on some widely traded stocks. The prime holder received all dividends paid to the stock and, at some maturity date, the lesser of the value of the stock and the strike price. The score holder received the remaining value of the stock on the maturity date, i.e. the greater of zero and the excess of the stock price over the strike price. For a limited time after the offering of these derivative securities, investors could tender a share of stock in exchange for a score and a prime. But, at any time before maturity, a score and a prime could be exchanged for a share of stock. Finally, primes and scores traded on the American Stock Exchange.

\footnotetext{
${ }^{4}$ It has been documented that the sum of the prime and score prices exceeds the price of their underlying stock. See Canina and Tuckman (1996) for tax-clientele explanation of this premium. For exposition of the effect of transaction costs on these instruments, see Jarrow and O’Hara (1989).
} 
The score can easily be recognized as a European call option on the underlying stock with 5 years to maturity when issued. Therefore, the Black-Scholes option pricing equation, adjusted for discrete dividends can be used to determine the theoretical price of the score.

$$
C_{t}\left(S_{t}-D_{t}\right) N(h)-k e^{-r t} N(h-\sigma \sqrt{\tau})
$$

where $S_{t}$ is the stock price at time $t, D_{t}=\sum_{k=t}^{T} E_{t}\left[e^{-r(k-t)} d_{k}\right], E_{t}$ is the expectations operator, $d_{k}$, is the expected cash dividend at ex-dividend date $k$ given information at time $t, \sigma$ is the volatility over the remaining life of the Trust, $r$ is the risk-free rate over the remaining life of the Trust, $T$ is the expiration date of the Trust, $\tau$ is the time to expiration, $N(\cdot)$ is the cumulative normal, and

$$
h=\frac{\left\{\ln \left[S_{t}-\sum_{k=t}^{T} \frac{e^{-r(k-t)} d_{k}}{K e^{r t}}\right]+\frac{1}{2} \sigma^{2} \tau\right\}}{\sigma \sqrt{\tau}}
$$

It is clear from Eq. (1) that the price of the score is positively related to the stock price and negatively related to the level of dividends. The impact of a change in dividends on the score price is the partial derivative of its price, Eq. (1), with respect to dividends. ${ }^{5}$

$$
\frac{\partial C}{\partial d_{1}}=N(h)\left[\frac{\partial S}{\partial d_{1}}-\sum_{j=k}^{J} e^{-r(j-r)}\right]
$$

where $l$ represents the first ex-dividend date at which the change becomes effective $(l>k), j$ represents the ex-dividend date, and $J$ represents the number of ex-dividend dates between time $t$ and $T$, the expiration date of the Trust.

\footnotetext{
${ }^{5}$ For simplicity, it is assumed that an announced change in dividends results in a parallel shift in all expected future dividends. For example, $\partial d_{1}$ represents the change in all dividends over the remaining life of the Trust. This is an upper bound on the dividend change. It is possible to let $\partial d_{1}$ represent the expected change in dividends over the remaining life of the Trust rather than the change in all dividends. In this case, the second term in brackets in Eq. (2) will be summed over the period of expected dividend changes rather than the life of the Trust.
} 
Eq. (2) shows that a dividend change has multiple effects on the score value. The first term, $\partial S / \partial d_{1}$ reflects the impact of a change in dividends on the stock price, which in turn will cause a change in the score price. The sign of the change in the score price is positively related to $\partial S / \partial d_{1}$ because the price of a call option is positively related to the stock price. The second effect, the last term in Eq. (2), $-\sum_{j=k}^{J} e^{-r(j-t)}$, represents the fact that scores, like call options, are not dividend protected. Its sign is negative because the score holder is not entitled to any dividends. Thus, the announcement of an increase in the level of dividends has two effects on the score price, as shown in Eq. (2): $\partial S / \partial d_{1}$ the impact of the change in dividends on the stock, is positively related to the price change of the score; and, $-\sum_{j=k}^{J} e^{-r(j-t)}$ is negative because scores are not dividend protected. The net effect which is the sum of the two, allows us to determine the market's view of the information. This is the topic of Section 2.

Prime holders receive all dividends until the termination date of the Trust. At termination, they receive the minimum of the stock price and the exercise price. Hence, the prime may be valued as a covered call. ${ }^{6}$

$$
P_{t}=S_{t}-C_{t}
$$

The sensitivity of the prime with respect to a change in the dividend level is

$$
\frac{\partial P}{\partial d_{1}}=[1-N(h)] \frac{\partial S}{\partial d_{1}}+\sum_{j=k}^{J} e^{-r(j-r)} N(h)
$$

Since both the first term, $[1-N(h)] \partial S / \partial d_{1}$ and the second term, $\sum_{j=k}^{J} e^{-r(j-t)} N(h)$ are nonnegative, an increase in dividends will never cause the prime price to fall.

\footnotetext{
${ }^{6}$ A covered call is a long position in the stock and a short position in the call. In the case of the prime, the score plays the role of the call.
} 
In Section 2, the relationship between the reaction of the stock, score and prime price to an announcement of a dividend change to the market's perception of the information conveyed in the announcement is described.

\section{Dividend changes, the market's perception and price changes}

Let us examine the relationship between investors' perception of the dividend announcement and the price change of the stock, score and the prime. There are three cases to consider. The market may consider the dividend announcement to reflect information about a permanent change in earnings (case 1), a temporary change in earnings (case 2) or not to contain any information about future earnings (case 3). ${ }^{7}$ Table 1 summarizes the sign of the price change of each asset for each of the three cases. A plus sign indicates a positive price change, a minus sign indicates a negative price change and a zero indicates no price change. For example, the plus sign (+), in line (1), column (1) means that if the market perceives a dividend increase to represent a change in permanent earnings then the stock price will increase.

If the dividend increase is interpreted to represent an increase in permanent or temporary earnings, then the stock price will increase (see columns (1) and (2), line (1)) according to the information content of dividend hypothesis. The stock price will also increase if the dividend increase represents a wealth transfer from the bondholders to the stockholders (see, column (2), line (1)) Note that it is impossible to distinguish between the first two cases by examining the reaction of the stock, alone. However, there will be no change in the stock price if the dividend change does not contain any information (see column (3), line (1)).

\footnotetext{
${ }^{7} \mathrm{~A}$ temporary change in the earnings is indistinguishable from a redistribution of wealth between stock and bond holders.
} 
Eq. (4) shows a nonnegative association between the price of the prime and the dividend. Therefore, if the dividend increases, then the prime will increase in each case (see columns (1)(3), line (2)).

Lines (4) and (5) show the multiple effects that an increase in dividends has on the score price. The score price change due to the first effect, 3S/3dh will be positive as long as the stock price change is positive (see columns (1) and (2), line (4)). However, if the dividend increase does not convey any information (case 3 ) then the stock price change, $\partial S / \partial d_{1}$ will equal zero and there will be no impact on the score (see column (3), line (4)). Since scores are not dividend protected, the second effect, $-\sum_{j=k}^{J} e^{-r(j-t)}$ will be negative for a dividend increase in each of the three cases.

The total effect on the score price (line (6)), depends on the relative magnitude of the two effects. This is evident from Eq. (2). As long as the change in the stock price, $\partial S / \partial d_{1}$, is greater than the sum of the present value of the dividend change over the remaining life of the Trust, $-\sum_{j=k}^{J} e^{-r(j-t)}$ the total effect on the score price is positive. The only way for this condition to hold is if the change in dividends reflects information about a change in earnings that is expected to be maintained beyond the expiration date of the Trust.

In sum, if there is an increase in the price of the stock, the score, and the prime, then the market perceives the announcement of a dividend change to reflect information about a permanent change in earnings of the firm. However, if only the stock and the prime prices increase but the score price does not change then the market perceives the dividend announcement to reflect a temporary change in the earnings of the firm or a wealth redistribution from the bondholders to the stockholders. Lastly, an increase in the prime price alone implies 
that the market perceives the announcement to contain no information about the earnings of the firm.

\section{Data and methodology}

Daily closing prices of the score $(C)$, the prime $(P)$, and the stock $(S)$, for each Americus Trust were obtained from the CRSP Daily File. The price is the closing price adjusted for stock splits and stock dividends. The sample period for each Trust consists of all data from the opening of trading through expiration. A list of the Trusts and sample periods is presented in Appendix A. The dividend data (the dividend amount, the announcement date of the dividend and the ex-day) were collected from the CRSP Monthly Master File. The sample contains 26 Trusts, of which 26 made dividend announcements during the sample period. There is a total of 517 dividend announcements, of which 85 are announcements of dividend increases made by 25 companies. Two companies announced a dividend decrease during the sample period.

The daily returns for the score (RC), the prime (RP), and the stock (RS) were computed as the log price relatives adjusted for dividends:

$$
\begin{gathered}
R C_{j t}=\ln \left(\frac{C_{j t}}{C_{j t-1}}\right) \\
R P_{j t}=\ln \left(\frac{P_{j t}+D P_{j t}}{P_{j t-1}}\right) \\
R S_{j t}=\ln \left(\frac{S_{j t}+D_{j t}}{S_{j t-1}}\right)
\end{gathered}
$$

where $j$ is the company index, $C_{j t}$ is the score price, $P_{j t}$ is the prime price, $S_{j t}$ is the stock price, $D_{j t}$ is the dividend paid to stock holders on the ex-dividend date $t$ (set to zero on all other days); 
$D P_{j t}$ is the dividend paid to prime holders on the ex-dividend date t, i.e. $D_{j t}-0.0125$ (set to zero on all other days).

Note that $\$ 0.0125$ was subtracted from each dividend payment to the prime because this is one of the commissions charged by the Trust. If the price of the score, prime or stock was not available at time $t$ then the return for the score, the prime and the stock were also given a missing value.

In order to examine empirically whether or not the market perceives an unexpected dividend change to reflect a permanent or temporary change in the earnings of the firm, a measure of the expected change in dividends must be derived. Ideally, we would only like to examine the announcement of dividend changes that are unanticipated by the market. In order to do so, we need a model of dividend expectations. The expectation model used in this study is a naive model. That is, it forecasts no change in dividends from one quarter to another.

$$
\widehat{D}_{j, q}=D_{j, q-1}
$$

where $\widehat{D}_{j q}$ is the expected dividend per share for the $j$ th firm prior to the announced date in the $q$ th quarter; $D_{j, q}$ is the actual dividend per share announced by the $j$ th firm in the $q$ th quarter.

Accordingly, if the announced dividend is greater than or less than the last actual dividend then the announced dividend represents either an unexpected increase or an unexpected decrease in dividends respectively. This naive model of dividend expectations was used to determine the sample of unanticipated dividend increases. The resulting sample contains 85 announcements of dividend increases made by 23 companies.

The market's perception of the information conveyed in dividend announcements is examined by testing the statistical significance of the unanticipated return of the score, the prime and the stock during the event period for the portfolio of announced dividend increases using the 
event study methodology. ${ }^{8}$ The mean model is used to estimate the expected return during the estimation period. The event period is defined as the day before through the day after the announcement date. The estimation period consists of 60 trading days prior to the event period. If there were less than 15 closing prices for the score, the prime and the stock in the event period, then the announcement was excluded from the final sample. The final sample contains 81 announcements of dividend increases made by 22 companies.

A brief description of the standard event study methodology used to compute the excess returns and $t$-statistics during the announcement period follows. First, the expected return was calculated for each of the three securities during the estimation period by event $I$, by company $j$

$$
\begin{aligned}
& \overline{R C_{\jmath l}}=\frac{\sum_{t=-61}^{-2} R C_{j i t}}{N_{j i}} \\
& \overline{R P_{\jmath l}}=\frac{\sum_{t=-61}^{-2} R P_{j i t}}{N_{j i}} \\
& \overline{R S_{\jmath l}}=\frac{\sum_{t=-61}^{-2} R S_{j i t}}{N_{j i}}
\end{aligned}
$$

where $t$ is the $t$ th day relative to a given announcement date $I$ for firm $j$, and $N_{j i}$ is the number of trading days in the estimation period for event $I$, company $j$.

The unexpected or excess return of the score, the prime and the stock, is calculated for each day $t$ in the event period, by event $I$, by company $j$. It is defined as the actual daily return minus the expected return.

$$
\begin{aligned}
& \hat{e}_{j i t}^{C}=R C_{j i t}-\overline{R C_{\jmath l}} \\
& \hat{e}_{j i t}^{P}=R P_{j i t}-\overline{R P_{\jmath l}}
\end{aligned}
$$

\footnotetext{
${ }^{8}$ See Brown and Warner $(1980,1985)$ for a detailed explanation of event study methodology.
} 


$$
\hat{e}_{j i t}^{S}=R S_{j i t}-\overline{R S_{j l}}
$$

where $t$ denotes the $t$ th day relative to a given announcement date $I$ for firm $j$. The excess returns are averaged across events and companies to compute the unexpected return for the entire portfolio of dividend increases for each day $t$ in the event period. ${ }^{9}$

$$
\bar{e}_{t}^{a}=\frac{\sum_{j=1}^{26} \sum_{i=1}^{I_{j}} \hat{e}_{j i t}^{a}}{\sum_{j=1}^{26} I_{j}} \quad \text { for } a=C, P, S
$$

where $\mathrm{I}_{\mathrm{j}}$ represents the number of announcements of dividend increases for company $\mathrm{j}$.

Lastly, the cumulative excess return is computed by adding the daily unexpected returns for the portfolio over the announcement period.

$$
\bar{e}^{a c}=\sum_{t=-1}^{1} \bar{e}_{t}^{-a c} \text { for a }=\mathrm{C}, \mathrm{P}, \mathrm{S}
$$

In order to test whether the cumulative excess return for the portfolio of dividend increases $\bar{e}^{a c}$ is significantly different from zero, t-statistics were calculated in the following manner. (1) Calculate the t-statistic for the unexpected return on the score C, the prime P and the stock S, by event day t, by announcement I:

$$
t\left(\hat{e}_{j i t}^{a}\right)=\frac{\hat{e}_{j i t}^{a}}{s e_{j i}^{a}} \quad \text { for } \mathrm{a}=\mathrm{C}, \mathrm{P}, \mathrm{S}
$$

where $s e_{j i}^{a}$ is the standard error of the unexpected returns calculated over the 60 day estimation period prior to the event period of each announcement. (2) Calculate the t-statistic for the unexpected return on the portfolio of announced dividend increases:

\footnotetext{
${ }^{9}$ All statistics are computed assuming independence.
} 


$$
t\left(\bar{e}_{t}^{a}\right)=\frac{\sum_{j=1}^{26} \sum_{i=1}^{I_{j}} t\left(\bar{e}_{j i t}\right)^{a}}{\sqrt{\sum_{j=1}^{26} I_{j}}} \text { for a=C,P,S }
$$

(3) Compute the appropriate test statistic for the event period:

$$
t^{c}\left(\bar{e}^{a}\right)=\frac{\sum_{t=-1}^{1} t\left(\bar{e}_{t}^{a}\right)}{\sqrt{3}} \quad \text { for a=C,P, S }
$$

\section{Results}

The null hypothesis is that the market perceives the announcement of a change in dividends as a temporary change in earnings versus the alternative hypothesis that the market expects the change in earnings to be long term. This hypothesis is tested by analyzing the statistical significance of the unexpected returns on the score, prime and stock over the announcement period. Table 2 presents the results.

The cumulative excess return on the score is statistically different from zero at the $1 \%$ significance level. The magnitude of the cumulative excess return is substantial, $1.44 \%$ over a 3 day period. This evidence is consistent with the hypothesis that the market perceives the information in dividend announcements to reflect a long- run change in earnings. ${ }^{10}$ The market's perception of the information conveyed by dividend announcements is consistent with managers' intentions as documented by Lintner (1956). The positive price reaction of the scores implies that the announcement of the change represents an increase in the permanent earnings of the firm to the market. The results are inconsistent with wealth redistribution being the primary motive for

\footnotetext{
${ }^{10}$ This assumes that the information content and wealth redistribution hypotheses are mutually exclusive. If they are not, it may be difficult to find evidence that supports the null hypothesis that the market perceives the dividend announcements to reflect a temporary change in earnings or a wealth redistribution.
} 
changing dividends. Under this hypothesis, the unexpected return on the score would have been insignificantly different from zero at most.

As shown in Table 2, the cumulative excess returns on the prime and the stock are positive and statistically significant. Given the positive excess return on the score, the positive excess return on the stock and the prime gives further support that the dividend announcement contains information. If the excess returns on the stock and the prime had been insignificantly different from zero or negative, then it would have led us to question the results found for the score. As shown, this was not found to be the case.

In order to ensure the validity of the results, additional analyses were performed. First, to make sure the results are not due to outliers, we performed a nonparametric sign test. The results are presented in Table 2. The z-statistics are 2.54, 13.45 and 2.76 for the score, prime and the stock respectively. It does not appear that outliers are the driving force behind the results. Because of the possibility of stale prices, especially for the score and the prime, the average daily dollar volume was computed across the announcement periods. The average daily dollar volume was over $\$ 6000000$ for the stock, over $\$ 500000$ for the prime and over $\$ 900000$ for the score. Liquidity is not a problem. The event dates were checked for clustering. If there is clustering and positive cross-sectional dependence, then the null hypothesis will be rejected incorrectly. No clustering was found. Lastly, the estimation and announcement periods were checked for other major announcements. Other announcements did not have an impact on the results.

\section{Conclusions}

This study examines whether the market perceives the information in dividend announcements to reflect a long-term (permanent) or short-term (temporary) change in the 
earnings of the firm. The paper distinguishes between a temporary and permanent change by analyzing the price reaction of scores around the announcement of dividend changes. It is shown that the price change of the score represents the market's valuation of the information in the announcement concerning the long- run change in the earnings of the firm, unlike the reaction of the stock price. The empirical evidence indicates that the market expects the dividend change to reflect a long-run change in earnings. The fact that the market perceives earnings increases to be permanent is consistent with the Lintner (1956) assertion that managers change dividends only when they expect the change in earnings to be permanent. 


\section{Acknowledgements}

Helpful comments from Yaakov Amihud, Stephen Brown, Stephen Figlewski, William Greene, Roni Michaely, William Silber, Bruce Tuckman and seminar participants at Boston College, Brown University and the University of Iowa are gratefully acknowledged. 
Table 1. The effect of the announcement of a dividend increase on the price of the stock, score and prime

\begin{tabular}{llll}
\hline & \multicolumn{3}{c}{ The sign of the price change } \\
\cline { 2 - 4 } & Case 1 & Case 2 & Case 3 \\
\hline Security & $\begin{array}{l}\text { Permanent change in } \\
\text { earnings }\end{array}$ & $\begin{array}{l}\text { Temporary change in } \\
\text { earnings }\end{array}$ & $\begin{array}{l}\text { No information about } \\
\text { earnings }\end{array}$ \\
& $(1)$ & $(2)$ & $(3)$ \\
(1) Stock & + & + & 0 \\
(2) Prime & + & + & + \\
(3) Score & + & + & 0 \\
(4) $\partial S / \partial d_{l}$ & - & - & - \\
(5) $\sum_{j=k}^{J} \mathrm{e}^{-r(j-t)}$ & & 0 & - \\
(6) Total score (4) $+(5)$ & & &
\end{tabular}

"Note. A dividend increase has multiple effects on the value of the score, as shown in lines (4) and (5): $\partial S / \partial d_{l}$ represents the impact of the dividend change on the stock which, in turn, affects the value of the score; and $\Sigma_{j=k}^{J} \mathrm{e}^{-r(j-t)}$ is due to the fact that scores are not dividend protected. 
Table 2. The cumulative excess returns over the 3 day announcement period on the score, the prime and the stock for dividend increases

\begin{tabular}{lllllr}
\hline Security & $\begin{array}{l}\text { Cumulative excess } \\
\text { return }\end{array}$ & t-statistic & $\begin{array}{l}\text { Number of posi- } \\
\text { tives }\end{array}$ & $\begin{array}{l}\text { Number of } \\
\text { negatives }\end{array}$ & $z$-statistic \\
\hline Score & 0.0144 & 2.3170 & 52 & 29 & 2.54 \\
Prime & 0.0089 & 6.2801 & 61 & 20 & 13.45 \\
Stock & 0.0058 & 2.7474 & 53 & 28 & 2.76 \\
\hline
\end{tabular}




\section{References}

1. Asquith, P., Mullins Jr., D.W., 1983. The impact of initiating dividend payments on shareholders’ wealth. J. Bus. 56, 77-95.

2. Black, F., 1976. The dividend puzzle. In: Meyers, S.C. (Ed.), Modern Developments in Financial Management. Dryden, Hinsdale, IL.

3. Black, F., Scholes, M.S., 1974. The effects of dividend yield and dividend policy on common stock prices and returns. J. Financ. Econom. 1, 1-22.

4. Brown, S., Warner, J., 1980. Measuring security price performance. J. Financ. Econom. 8, 205-258. Brown, S., Warner, J., 1985. Using daily stock returns: the case of event studies. J. Financ. Econom. 14, 3-31.

5. Canina, L., Tuckman, B., 1996. Clientele effects in the market for scores and primes. Financ. Manag. J. 25, 78-94.

6. Dhillon, U.S., Johnson, H., 1994. The effect of dividend changes on stock and bond prices. J. Financ. 49, 281-289.

7. Galai, D., Masulis, R., 1976. The option pricing model and the risk factor of stocks. J. Financ. Econom. 3, 53-82.

8. Gonedes, N.J., 1978. Corporate signaling, external accounting, and capital market equilibrium: evidence on dividends, income, and extraordinary items. J. Account. Res. 16, 26-79.

9. Handjinicolaou, G., Kalay, A., 1984. Wealth redistributions or changes in firm value: an analysis of returns around dividend announcements. J. Financ. Econom. 13, 35-63.

10. Healy, P., Palepu, K., 1988. Earnings information conveyed by dividend initiations and omissions. J. Financ. Econom. 21, 149-176. 
11. Jarrow, R., O’Hara, M., 1989. Primes and scores: an essay on market imperfections. J. Financ. 44, 1263-1288.

12. Jensen, M., Meckling, W., 1976. Theory of the firm: managerial behavior, agency costs and capital structure. J. Financ. Econom. 3, 305-360.

13. Kalay, A., 1982. Stockholder-bondholder conflict and dividend constraints. J. Financ. Econom. 10, 211-233.

14. Lintner, J., 1956. Distribution of incomes of corporations among dividends, retained earnings, and taxes. Am. Econom. Rev. 61, 97-113.

15. Myers, S., 1977. Determinants of corporate borrowing. J. Financ. Econom. 5, 147-175.

16. Smith, C., Warner, J., 1979. On financial contracting: an analysis of bond covenants. J. Financ. Econom. 7, 117-161.

17. Watts, R., 1973. The information content of dividends. J. Bus. 46, 191-211.

18. Yoon, S.Y., Starks, L.T., 1995. Signaling, investment opportunities, and dividend announcements. Rev. Financ. Stud. 8, 995-1019. 
Appendix A. List of Trusts

\begin{tabular}{|l|l|l|}
\hline \multicolumn{1}{|c|}{ Company Name } & \multicolumn{1}{|c|}{ Start date } & Expiration date \\
\hline American Home Products & 861213 & 911120 \\
\hline Bristol Meyers & 870217 & 920214 \\
\hline Eastman Kodak & 870428 & 920415 \\
\hline General Electric & 870427 & 920511 \\
\hline DuPont & 870128 & 920518 \\
\hline Merck & 870326 & 920414 \\
\hline Amoco & 870402 & 920330 \\
\hline Dow Chemical & 870423 & 920518 \\
\hline Union Pacific & 870423 & 920415 \\
\hline Proctor \& Gamble & 870515 & 920601 \\
\hline Chevron & 870615 & 920701 \\
\hline Atlantic Richfield & 870706 & 920701 \\
\hline Mobil & 870701 & 920630 \\
\hline General Motors & 870706 & 920630 \\
\hline Sears Roebuck & 870622 & 920715 \\
\hline Coca Cola & 870715 & 920715 \\
\hline IBM & 870720 & 920630 \\
\hline American Express & 870713 & 920824 \\
\hline Philip Morris & 870729 & 920727 \\
\hline Johnson and Johnson & 870813 & 920630 \\
\hline Xerox & 870729 & 900920 \\
\hline Hewlett Packard & 870729 & 920715 \\
\hline Ford Motor & 870527 & 920630 \\
\hline Exxon & 850910 & 900920 \\
\hline GTE & 870622 & 920715 \\
\hline AT\&T & 870212 & 920214 \\
\hline
\end{tabular}

